Mеталлофиз. новейшие технол. / Metallofiz. Noveishie Tekhnol. () 2017 ИМФ (Институт металлофизики 2017, т. 39, № 11, сc. 1511-1523 / DOI: 10.15407/mfint.39.11.1511 им. Г. В. Курдюмова НАН Украины) Оттиски доступны непосредственно от издателя

Фотокопирование разрешено только

Напечатано в Украине.

в соответствии с лицензией

PACSnumbers:61.72.Ff,61.72.Qq, 62.20.Qp, 68.37.Hk,81.05.Ni,81.20.Ev,81.40.Pq,82.80.Pv

\title{
The Effect of Metal Fibres and Borax Powders on the Wear and Friction Performances of the Organic Based Brake Pads
}

\author{
İrem Burcu Algan and Adem Kurt
}

\author{
Gazi University, \\ Faculty of Technology, Department of Materials and Metallurgy, \\ 06500 Ankara, Turkey
}

\begin{abstract}
The use of various materials in brake pad compositions is widely studied. In this study, the borax powders or the copper or bronze fibres are added in nonasbestos organic brake pad composition to examine the effects of type and quantity of additive on the friction and wear characteristics of brake pads. Firstly, three different specimen groups are developed by powder metallurgy method, which contain various amounts $(1.5,3,4.5$ and $6 \%$ weight) of borax powder, copper fibre, and bronze fibre. The mixtures are blended with an industrial-type mixer, pressed by hydraulic press, and then they are postsintered at $185^{\circ} \mathrm{C}$ for 24 hours. The friction-wear tests of specimens are performed by means of the Chase Machine according to the SAE-661 test standard, and then friction surfaces of the specimens are analysed with a scanning electron microscope. Hardness tests are performed according to the Brinell Scale test method. Test results show that, while addition of different amounts of borax powder enhances the wear resistance of brake pads, addition of copper and bronze fibres increases recovery, normal and hot friction coefficients' values with increasing amount of metallic fibre.
\end{abstract}

Key words: non-asbestos organic brake pads, borax, metallic fibre, wear resistance, friction coefficient.

Досліджено використання різних матеріялів у композиціях гальмівних дисків. Порошки бури, мідні чи то бронзові волокна додавалися до складу безазбестового органічного гальмівного диску з метою дослідження впливу типу та кількости добавки на характеристики тертя та зносу гальмів-

Corresponding author: Adem Kurt

E-mail: ademkurt@gazi.edu.tr

Please cite this article as: İrem Burcu Algan and Adem Kurt, The Effect of Metal Fibres and Borax Powders on the Wear and Friction Performances of the Organic Based Brake Pads, Metallofiz. Noveishie Tekhnol., 39, No. 11: 1511-1523 (2017), DOI: $10.15407 /$ mfint.39.11.1511. 
них дисків. Вперше методою порошкової металургії було розроблено три різних групи зразків, що містять різну кількість порошку бури, мідних і бронзових волокон $(1,5,3,4,5$ і $6 \%$ ваги). Суміші готувалися за допомогою мішалки промислово типу, пресувалися гідравлічним пресом, а потім спікалися за температури $185^{\circ} \mathrm{C}$ протягом 24 годин. Тестування зразків на тертя-знос проводили за допомогою Chase Machine відповідно до стандарту SAE 661; потім поверхні тертя зразків досліджувалися сканівним електронним мікроскопом. Випробування на твердість проводили за Бринеллевою методою. Результати випробувань свідчать, що, у той час як додавання різної кількости порошку бури підвищує зносостійкість гальмівних дисків, додавання мідних та бронзових волокон збільшує показники відновлення, значення коефіцієнтів нормального та гарячого тертя зі збільшенням кількости металевого волокна.

Ключові слова: безазбестові органічні гальмівні диски, бура, металеве волокно, зносостійкість, коефіцієнт тертя.

Изучено использование различных материалов в композициях тормозных дисков. Порошки буры, медные или бронзовые волокна добавлялись в состав безасбестового органического тормозного диска, и исследовалось влияние типа и количества добавки на характеристики трения и износа тормозных дисков. Впервые методом порошковой металлургии были разработаны три разных группы образцов, содержащих различное количество порошка буры, медных и бронзовых волокон $(1,5,3,4,5$ и $6 \%$ веса). Смеси готовились с помощью мешалки промышленно типа, прессовались гидравлическим прессом, а затем спекались при температуре $185^{\circ} \mathrm{C}$ в течение 24 часов. Тестирование образцов на трение-износ проводили с помощью Chase Machine в соответствии со стандартом SAE 661; затем поверхности трения образцов исследовались сканирующим электронным микроскопом. Испытания на твёрдость проводили по методике Бринелля. Результаты испытаний показывают, что, в то время как добавление разного количества порошка буры повышает износостойкость тормозных дисков, добавление медного и бронзового волокон увеличивает показатели восстановления, значения коэффициентов нормального и горячего трения с увеличением количества металлического волокна.

Ключевые слова: безасбестовые органические тормозные диски, бура, металлическое волокно, износостойкость, коэффициент трения.

(Received October 5, 2017)

\section{INTRODUCTION}

Brake pad is a member of the brake system and formed by a combination of numerous components, and it is used to decelerate/stop vehicles. Brake pad components transform physically and chemically during braking, which identifies the friction-wear behaviour. For this reason, the selection of components based on their characteristics in macro- and microlevels is crucial. Braking-related friction and wear 
behaviour change depending upon driving conditions, the composition of brake pads, production parameters, and friction film interfaces between the friction material and the rotor. Therefore, in the last decade, experimental studies have aimed to provide stable friction, durability, equal abrasion resistance, and low noise and vibration [1, 2].

Brake pads are classified according to the type of base material such as metallic, carbon, and non-asbestos organic pads. Metallic-based pads consist of metallic components, such as steel and copper, carbon based pads have graphite, and non-asbestos organic pads have nonferrous metals, Kevlar, and fiberglass. Studies on organic-based brake pads have increased due to wide availability of the organic materials used in such pads and also because their density is much lower compared to that of metallic pads. The use of steel, brass, and copper in brake pad compositions provides an efficient heat transfer from the friction surface because of their high thermal conductivity [3]. In recent years, researchers have been conducting investigations to find new materials to maintain the friction coefficient stability. As boron and its compounds have high physical and mechanical properties, they are utilized in many applications, including brake pad compositions [4-7]. The present study aims to investigate the effects of borax powder (a compound of boron) and copper and bronze fibres on friction and wear characteristic of non-asbestos organic brake pads.

\section{EXPERIMENTAL DETAILS}

\subsection{Specimens}

Three types of ingredients (borax powder, copper and bronze fibres) were added with different rates in the commercial organic based brake pad composition. Firstly, base specimen and three different specimen groups were prepared by powder metallurgy method that contain $1 \%$, $3 \%$, and $5 \%$ borax powder $\left(\mathrm{Na}_{2} \mathrm{~B}_{4} \mathrm{O}_{7} \cdot 10 \mathrm{H}_{2} \mathrm{O}\right), 1.5 \%, 3 \%, 4.5 \%$, and $6 \%$ copper fibres, and $1.5 \%, 3 \%, 4.5 \%$, and $6 \%$ bronze fibres $(86 \% \mathrm{Cu}-$ $14 \% \mathrm{Sn}$ ) by weight. Copper and bronze fibres were $1 \mathrm{~mm}$ in size.

The mixtures were blended with an industrial type mixer for $3 \mathrm{~min}$, pressed in mould $(86 \mathrm{~mm} \times 55 \mathrm{~mm}$ ) under $15 \mathrm{MPa}$ pressure, and postsintered at $185^{\circ} \mathrm{C}$ for 24 hours. Table 1 shows the ingredients of the composition.

Sintered samples were resized with an ATM Brilliant 250 abrasive cutting device according to the SAE 661 test standard $(25 \mathrm{~mm} \times 5 \mathrm{~mm} \times$ $\times 7 \mathrm{~mm}$ ). Then, their densities were calculated according to the Archimedes principle.

Samples were named according to type of additive: BX indicates borax powder, $\mathrm{CF}$ indicates copper fibre, and $\mathrm{BF}$ indicates bronze fibre. Density values were given in Table 2. 


\subsection{Characterizations of Composites}

Friction tests were performed using a Chase Machine friction-wear test (Pyramid Engineering, Serial Number: 120302) according to the SAE 661 test standard. After brake pad specimens were cut in sizes of $25 \mathrm{~mm} \times 25 \mathrm{~mm} \times 7 \mathrm{~mm}$, they were scrubbed with grey cast iron drum to simulate driving conditions, then friction force and temperature were measured, and data were transferred to the computer.

Hardness values of the specimens were measured by means of the Emco Test Duravision 2000 hardness test machine before and after the test with the Brinell Scale (Brinell-S) test method.

Surface characteristics of the brake pad specimens were analysed

TABLE 1. Ingredients in brake pad composition.

\begin{tabular}{ll}
\hline \multicolumn{1}{c|}{ Classification } & \multicolumn{1}{c}{ Materials } \\
\hline Binder & Phenolic resin \\
Fillers & Barite, calcium carbonate \\
Reinforcements & Glass fibre, steel fibre, Aramid fibre, PAN \\
Abrasives & Aluminium oxide, iron oxide \\
Friction modifiers & $\begin{array}{l}\text { Metal oxide, metal sulphide, borax powder, bronze } \\
\text { fibre, copper fibre }\end{array}$ \\
Lubricant & Graphite \\
\hline
\end{tabular}

TABLE 2. Density values according to ingredient type and percentage.

\begin{tabular}{l|c}
\hline \multicolumn{1}{c|}{ Samples } & Density $\left(\mathrm{g} / \mathrm{cm}^{3}\right)$ \\
\hline Base (non-asbestos organic pad composition) & 2.1 \\
BX1 & 2.1 \\
BX3 & 2.2 \\
BX5 & 2.3 \\
CF1.5 & 2.1 \\
CF3 & 2 \\
CF4.5 & 1.9 \\
CF6 & 2 \\
BF1.5 & 2.1 \\
BF3 & 2 \\
BF4.5 & 2 \\
BF6 & 2 \\
\hline
\end{tabular}


using a Jeol JEM 6060 LV SEM, and energy dispersive $\mathrm{x}$-ray spectroscopy (EDX) was performed on the specimens.

\section{RESULTS}

\subsection{Friction-Wear Behaviour}

The SAE-J661 standard is given in Table 3. According to this standard, friction coefficient values at the fade and recovery stages have different features. For example, fade stage starts when the temperature of the drum is $82^{\circ} \mathrm{C}$, the heater gets activated until the temperature reaches at $345^{\circ} \mathrm{C}$, and then friction coefficient values were recorded.

After this stage completion, heater stops and cooler steps in. Temperature decreases gradually at the recovery stage, and friction coefficient values are recorded.

To understand the friction-wear characteristic of the specimens at the fade and recovery stages clearly, some of performance parameters were identified [8-10]. These parameters are following: normal friction coefficient $(\mu)$ : average $\mu$ value at $93,121,149$, and $205^{\circ} \mathrm{C}$; hot friction coefficient $(\mu)$ for fade: average $\mu$ value at $345,317,289,261$, and $233^{\circ} \mathrm{C}$; hot friction coefficient $(\mu)$ for recovery: average $\mu$ value at 261,205 , and $149^{\circ} \mathrm{C} ; \mu$-fade: minimum $\mu$ value at the fade stage

$$
\% \text { fade rate }=100\left(\mu_{\min } \times \mu_{\max }\right) ;
$$

$\mu$-recovery: maximum $\mu$ value at the recovery stage

$$
\% \text { recovery rate }=100\left(\mu_{\min } \times \mu_{\max }\right) \text {; }
$$

TABLE 3. Stages of SAE-J661 test standard.

\begin{tabular}{l|c|c|c|c|c|c|c|c}
\hline \multicolumn{1}{c|}{ Name } & Speed & Load & $\begin{array}{c}\text { On } \\
\text { time }\end{array}$ & $\begin{array}{c}\text { Off } \\
\text { time }\end{array}$ & App. & $\begin{array}{c}\text { Temp. } \\
\text { L }\end{array}$ & $\begin{array}{c}\text { Temp. } \\
\text { H }\end{array}$ & $\begin{array}{c}\text { Temp. } \\
\text { Mode }\end{array}$ \\
\hline Burnish & 308 & 45 & 1200 & 0 & 1 & 0 & 93 & Strict \\
Reset & 205 & 23 & 300 & 0 & 1 & 0 & 93 & Strict \\
Baseline-1 & 411 & 67 & 10 & 20 & 20 & 82 & 104 & Auto \\
Fade-1 & 411 & 67 & 600 & 0 & 1 & 82 & 289 & Heater \\
Recovery-1 & 411 & 67 & 10 & 0 & 4 & 261 & 93 & Blower \\
Wear & 411 & 67 & 20 & 10 & 100 & 193 & 205 & Auto \\
Fade-2 & 411 & 67 & 600 & 0 & 1 & 82 & 345 & Heater \\
Recovery-2 & 411 & 67 & 10 & 0 & 5 & 317 & 93 & Blower \\
Baseline-2 & 411 & 67 & 10 & 20 & 20 & 82 & 104 & Auto \\
\hline
\end{tabular}




$$
\begin{gathered}
\% \text { thickness loss rate }= \\
=\frac{\text { thickness before test }- \text { thickness after test }}{\text { thickness before test }} \cdot 100 \text {. }
\end{gathered}
$$

As seen in Figure 1, the highest $\mu$ value at the fade stage is BX1 and the friction coefficient increased with temperature increase up to $205^{\circ} \mathrm{C}$. At the recovery stage, the friction characteristics of the samples changed and the base sample had the highest value. The cause of fluctuation at this stage was attributed to non-uniform thermal loads [7]. Figure 1, $a$ shows fade, recovery, normal and hot friction coefficients. The desired $\mu$ values of industrial brake pads are between 0.3 and 0.4 .

Standard test stages involve three basic parameters: load, temperature, and speed $[11,12]$. According to these parameters, $\mu$-fade and normal $\mu$ values of borax-added specimens are low; however, $\mu$ recovery and hot friction coefficients are average in present study. The BX5 has higher performance than other borax-added specimens do; however, base sample has the highest performance. Results indicate that the addition of borax powder does not increase the brake pad performance. The copper-fibre-added samples generally have good fric-
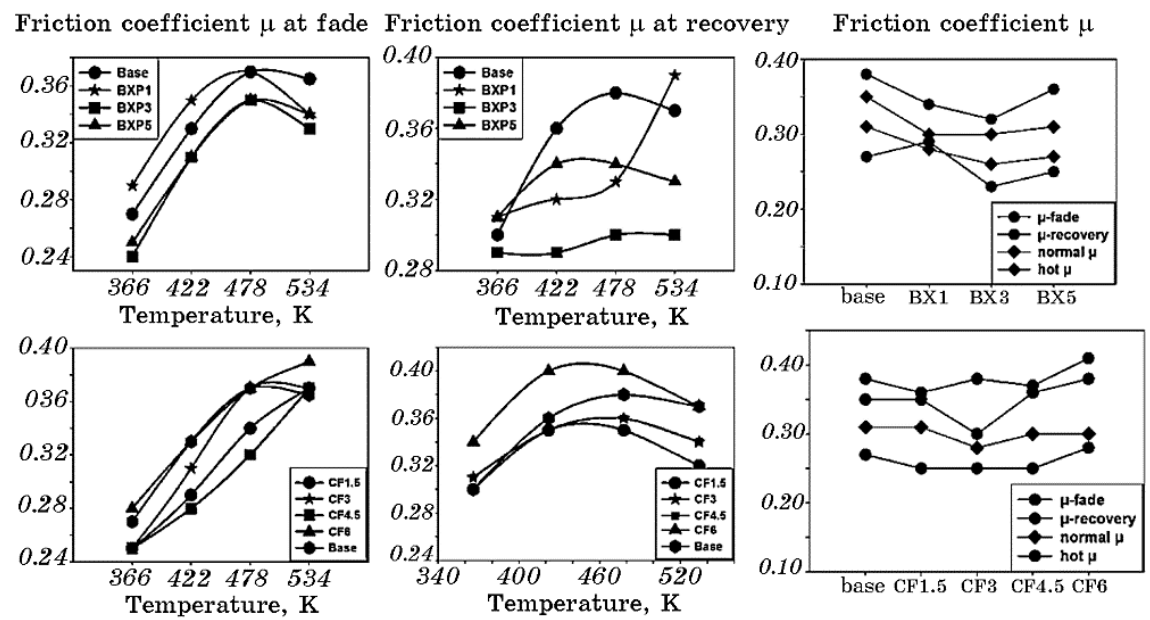

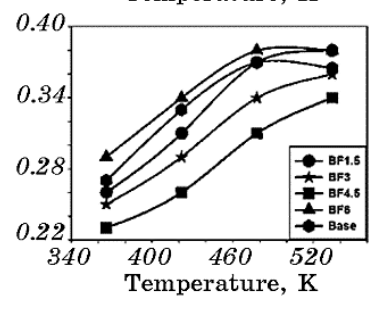

$a$

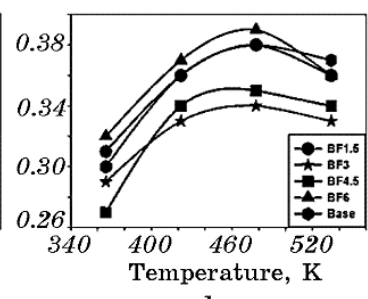

$b$

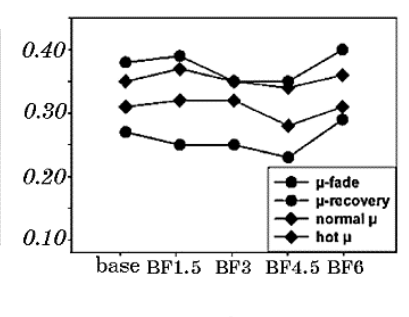

$c$

Fig. 1. Friction test results at the fade $(a)$ and recovery $(b)$ stages, and general characteristics of fade, recovery, normal and hot friction coefficient values $(c)$. 
tion characteristics because the thermal conductivity coefficient of copper is high $(\cong 401 \mathrm{~W} /(\mathrm{m} \cdot \mathrm{K}))$ and the generated heat is transferred efficiently for this reason. This situation improves organic brake pad friction coefficient. Furthermore, normal and hot friction coefficients increase with increasing copper fibre rate, thus CF6 (copper 6\% wt.) has the highest performance. Fade and recovery characteristics of the bronze fibre-added specimens are nearly same with the copper fibreadded specimens, however, the addition of copper enhanced the $\mu$-fade values unlike bronze, which has lower thermal conductivity than bronze $\left(k_{\text {bronze }} \cong 354.3 \mathrm{~W} /(\mathrm{m} \cdot \mathrm{K})\right)$. The rest results indicate that friction coefficient values increase with temperature up to $205^{\circ} \mathrm{C}$, and then decrease from this temperature, which is similar to resin behaviours at high temperature and bond strengths between brake pad components as described in the literature [5].

Figure 2 shows wear behaviour and fade and recovery rates for all samples. Bijwe et al. stated that acceptable \% fade rate between 80 and 100 and recovery rate between $75 \%$ and $100 \%$ [11]. Although the fade
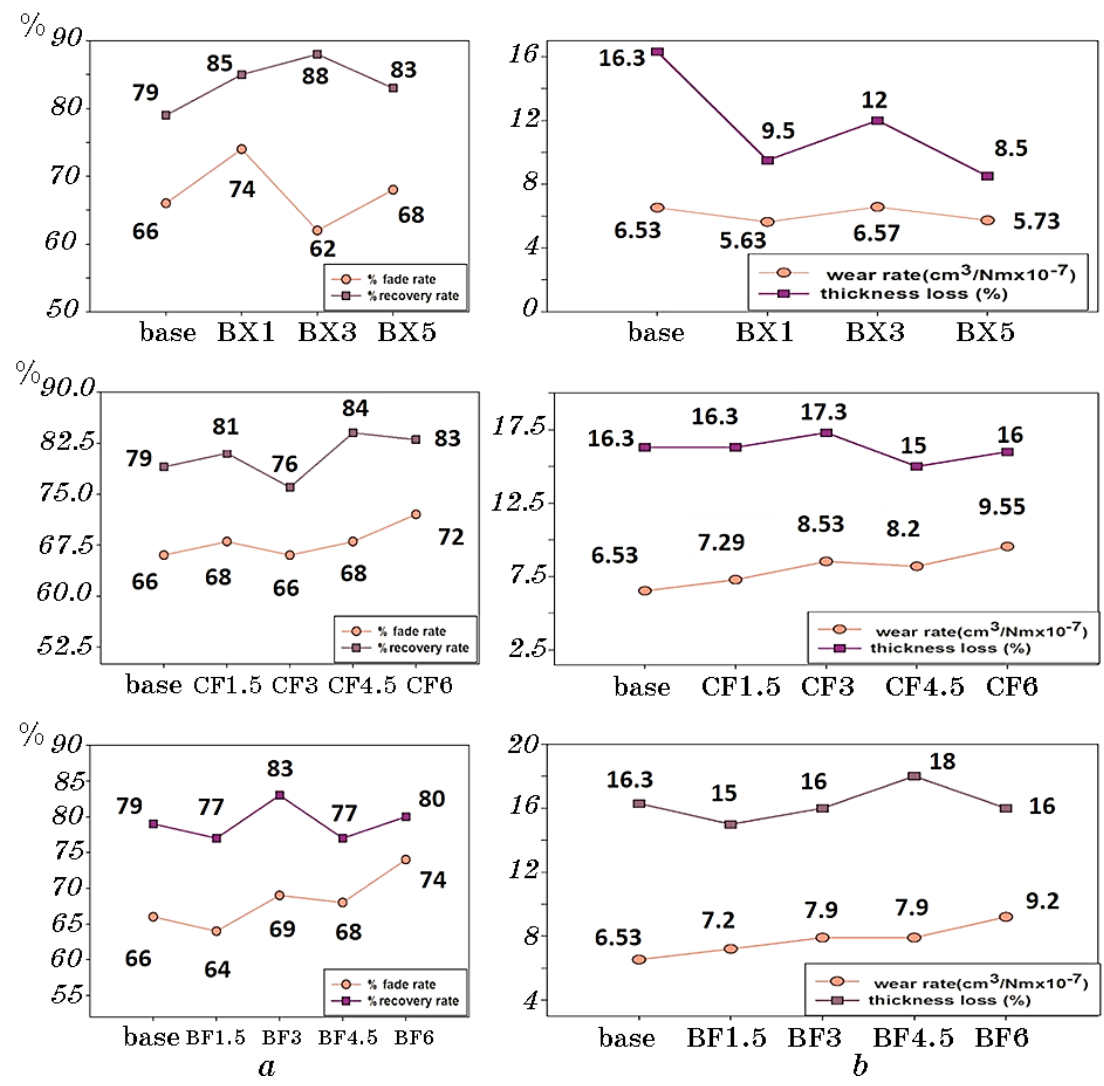

Fig. 2. Fade and recovery rate (a), wear rate and thickness loss $(b)$. 
rate of borax powder-added specimens is below the industrial expectation, their recovery rate is high. The addition of borax improves the recovery performance of organic brake pads slightly; however, their fade characteristic was substantially inadequate. The examination of the wear behaviour of borax-added specimens showed that wear rate and thickness loss decreased with increasing rate of borax weight, which indicates that wear resistance increased partially with increasing borax rate as the composite density (Table 2) increased. Metallicfibre addition in the brake pad composition results in inclusions, which increases the thermal conductivity and provides effective heat removal as reported in the literature. Furthermore, metallic materials exhibit aggressive behaviour that abrades and renews the layer on the interface between brake pad and disc. Thereby, both thermophysical properties and the tribofilm quality improve the fade resistance of the brake pad [9]. Based on this characteristic, wear rate and thickness loss increase with increasing copper and bronze rates, as seen in Fig. 2. Even though fade rate is low, recovery rate is high for copper-added and bronze-added specimens.

\subsection{Hardness Results}

Figure 3 shows the hardness values of specimens obtained by the friction test based on the Brinell-S method. Borax-added specimens exhibit higher hardness values than the base specimen, and BX3 has the highest hardness due to the work hardening caused by the increasing temperature during friction. Hardness values of copper-added and

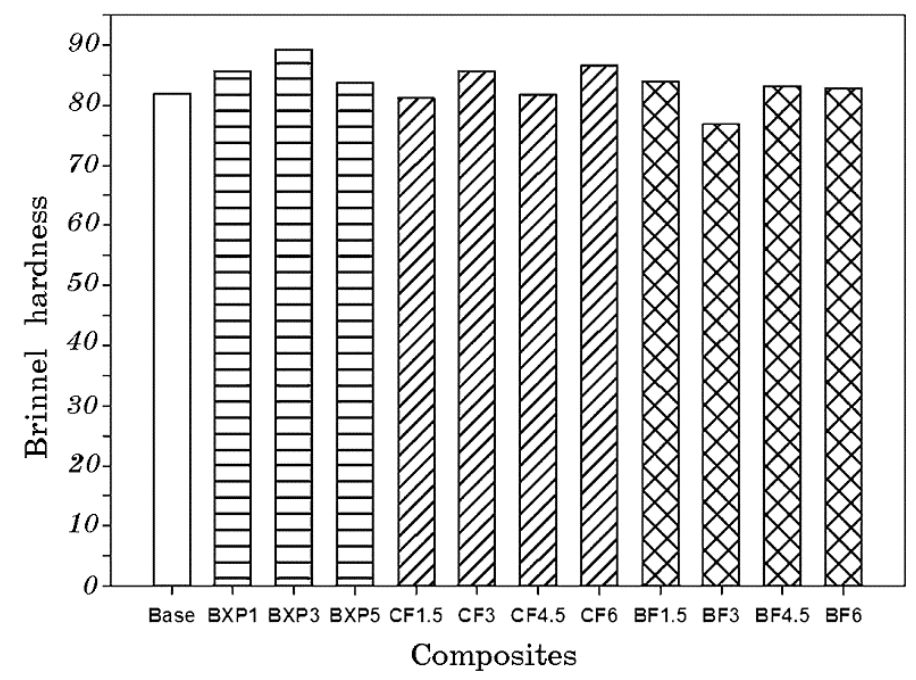

Fig. 3. Brinell-S hardness results of specimens after friction test. 
bronze-added specimens are high because metallic fibres increase wear and deformation. The increase of hardness leads to noise, thus bronzeadded specimens appear to be more advantageous than the other groups.

\subsection{SEM Observations}

The friction surface was analysed using SEM in combination with energy dispersive $x$-ray spectroscopy (EDS) mapping analysis to understand the relationship between worn surfaces and friction-wear characteristics of organic-based brake pads. Micrographs clearly show four distinct regions for all the specimen groups, which are black, white, grey, and wear debris. The EDS analysis indicates for all groups that the black region involves substantial amount of $\mathrm{C}, \mathrm{O}$, and $\mathrm{S}$ as well as a slight amount of $\mathrm{B}, \mathrm{Cu}$, or $\mathrm{Sn}$ (according to type of addition); the white region involves $\mathrm{O}, \mathrm{Ca}$; the grey region involves $\mathrm{C}, \mathrm{Ca}, \mathrm{O}$, and $\mathrm{Fe}$; and wear debris region involves $\mathrm{Fe}, \mathrm{O}, \mathrm{Al}, \mathrm{Si}$, and $\mathrm{Ca}$. Regional EDS results were given in Table 4 for some specimens. Figure 4 shows micrographs

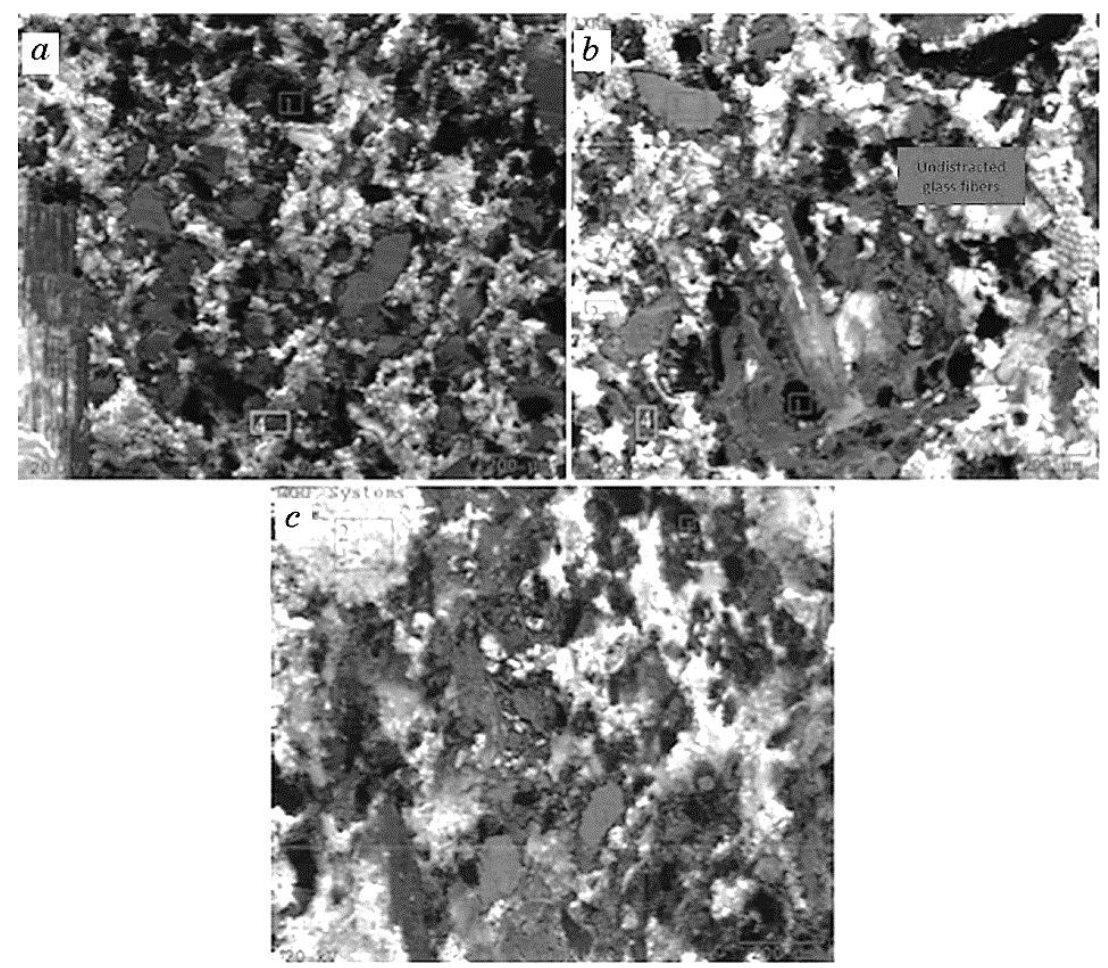

Fig. 4. SEM micrographs $(\times 200)$ of borax powder-added specimens BX1 $(a)$, BX3 $(b)$, and BX5 (c). 
TABLE 4. Regional EDS results for certain samples.

\begin{tabular}{|c|c|c|c|c|c|c|c|c|c|}
\hline Regions & Samples & BX3 & BX5 & CF3 & CF4.5 & CF6 & BF3 & BF4.5 & BF6 \\
\hline \multirow{7}{*}{ Black } & $\mathrm{C}$ & 76.8 & - & 85.8 & 84 & 94 & 94 & 38 & 90 \\
\hline & $\mathrm{O}$ & 5.8 & 5.1 & 6.6 & 11.2 & 3 & - & 20.4 & 4 \\
\hline & $\mathrm{S}$ & - & - & - & 3 & - & - & - & - \\
\hline & B & 15.7 & 92.5 & - & - & - & - & - & - \\
\hline & $\mathrm{Fe}$ & - & - & - & - & - & - & 24.8 & - \\
\hline & $\mathrm{Cu}$ & - & - & - & - & - & - & - & - \\
\hline & Sn & - & - & - & - & - & 2.4 & 4.2 & 2 \\
\hline \multirow{9}{*}{ White } & $\mathrm{C}$ & 74.1 & - & 69.4 & 73.7 & 11.5 & 80 & 41 & - \\
\hline & $\mathrm{O}$ & 5.8 & - & 27.2 & 20.2 & 28 & 15 & 19 & 29.3 \\
\hline & $\mathrm{Ca}$ & - & 28.2 & - & - & 40.4 & - & 17 & 23 \\
\hline & $\mathrm{Fe}$ & - & 14 & - & - & - & - & 12.4 & - \\
\hline & B & 16 & - & - & - & - & - & - & - \\
\hline & $\mathrm{Sn}$ & - & - & - & - & - & - & - & 8 \\
\hline & $\mathrm{Si}$ & - & 43 & - & - & - & - & - & 27 \\
\hline & $\mathrm{Ti}$ & - & - & - & - & 5 & - & - & - \\
\hline & $\mathrm{Al}$ & - & 10.4 & - & - & - & - & - & - \\
\hline \multirow{8}{*}{$\begin{array}{l}\text { Wear } \\
\text { debris }\end{array}$} & $\mathrm{O}$ & 7.7 & - & - & - & - & - & - & - \\
\hline & $\mathrm{Al}$ & - & - & - & - & - & - & - & - \\
\hline & $\mathrm{Fe}$ & 84.6 & 91.3 & 86.8 & 88.4 & 85.7 & 79 & 85 & 10.5 \\
\hline & $\mathrm{Ca}$ & - & 2.7 & - & - & - & - & - & - \\
\hline & $\mathrm{O}$ & - & - & - & - & 5.1 & 7 & - & 17 \\
\hline & $\mathrm{Cu}$ & - & - & 4.1 & 5.4 & 4.1 & - & - & - \\
\hline & $\mathrm{Sn}$ & - & - & - & - & - & 3.5 & 6 & 53.5 \\
\hline & $\mathrm{Si}$ & 3 & 3.1 & - & - & - & - & - & - \\
\hline \multirow{9}{*}{ Grey } & $\mathrm{O}$ & 31.4 & - & - & 33.4 & 21.1 & 20 & 23.3 & 32 \\
\hline & $\mathrm{Fe}$ & 14 & 41.9 & 92.7 & 8.7 & - & 12.3 & 21 & - \\
\hline & $\mathrm{C}$ & 30.5 & - & - & 43.2 & 65.4 & 50.1 & 37 & 27 \\
\hline & $\mathrm{Ca}$ & - & 27 & - & 9.3 & - & - & 5 & 27.3 \\
\hline & $\mathrm{Si}$ & - & 15 & - & - & - & - & - & - \\
\hline & $\mathrm{Sn}$ & - & - & - & - & - & - & - & 6 \\
\hline & $\mathrm{Al}$ & - & 6.1 & - & - & - & - & - & - \\
\hline & $\mathrm{Mg}$ & - & - & - & - & 5.7 & - & - & - \\
\hline & $\mathrm{Cu}$ & - & - & 3.2 & - & - & - & - & - \\
\hline
\end{tabular}

of borax-added specimens, where black-white regions take a large proportion.

According to the EDS results, the existing boron-oxygen compounds appear to have improved the wear resistance of brake pads as seen in Fig. 2. In Figure 4, $b$, it is observed that undistracted glass fibres are perpendicularly oriented towards the sliding direction due to the adhesive bonding of glass fibres at high temperatures.

The EDS results of the wear debris region indicate that this region 


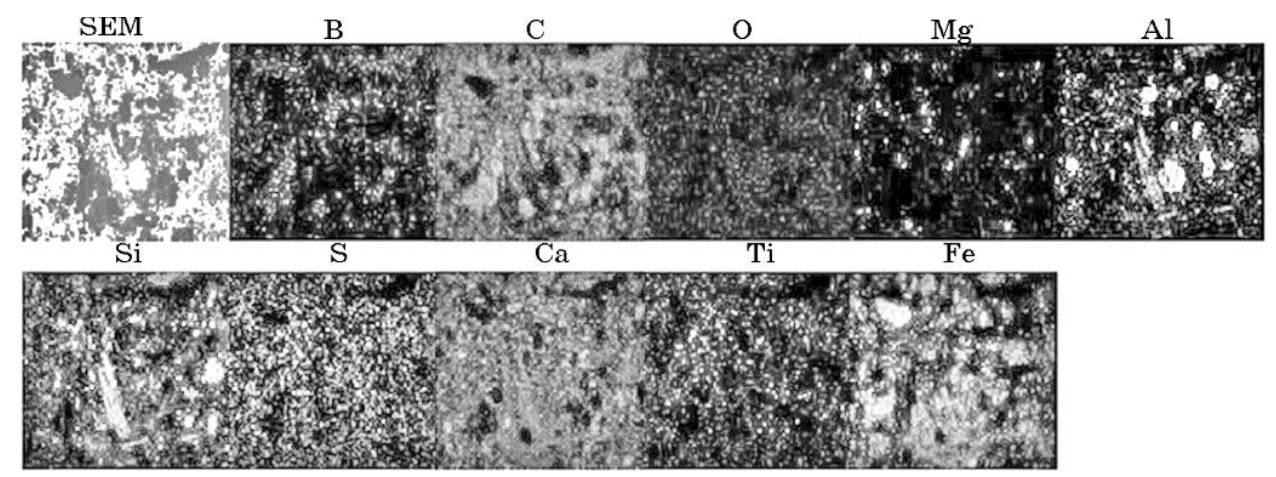

Fig. 5. EDS mapping image of BX3.

involves $\mathrm{Fe}$, and $\mathrm{O}$, as well as $\mathrm{Ca}, \mathrm{Si}$, and $\mathrm{Al}$, as reported in the literature. The amount of this region is higher in BX1 compared to the other borax powder-added specimens. Larger wear debris regions are caused by the numerous contact points in the friction interfaces [13, 14]. For this reason, BX1 appears to have the highest hot friction coefficient, normal friction coefficient, and $\mu$-fade. A sample EDS mapping image provided in Fig. 5 clearly shows that the components of the composite are dispersed homogeneously.

Wear debris are fragmented and spread on the wear surface and also embedded into the matrix as shown in Fig. 6, $c$, which was considered to be a factor increasing the friction coefficient.

Table 4 shows clearly that the amounts of $\mathrm{Fe}$ and $\mathrm{O}$ are high in wear debris region for certain sample, and they control the wear-friction behaviour as reported in the literature $[13,16,17]$. Since broken particles coming from the grey cast iron disc accumulate in wear surfaces, the amount of $\mathrm{Fe}$ is the highest in this region [18]. As apparent in Figs. $6, a$ and $7, d$, the long and large wear debris regions are secondary regions consisting of graphite and aramid fibres, which appear to be leading to a decrease in the friction coefficient. BF4.5 and BF6 involve substantial amount of $\mathrm{Fe}$ and $\mathrm{Cu}$ elements, which appears to be providing an increase in $\mu$-recovery $(0.36-0.41)$ and recovery rate. Additionally, Figure 7 shows that wear debris regions are much larger in BF6 because its normal $\mu$, hot $\mu$, and recovery $\mu$ values are high. Moreover, wear rate and thickness loss increased especially for BF4.5.

\section{DISCUSSION}

In the present study, the effect of type and quantity of additive on the wear and friction behaviours of non-asbestos commercial organic brake pad compositions was examined. The important conclusions resulting from the above present study are as follow. 


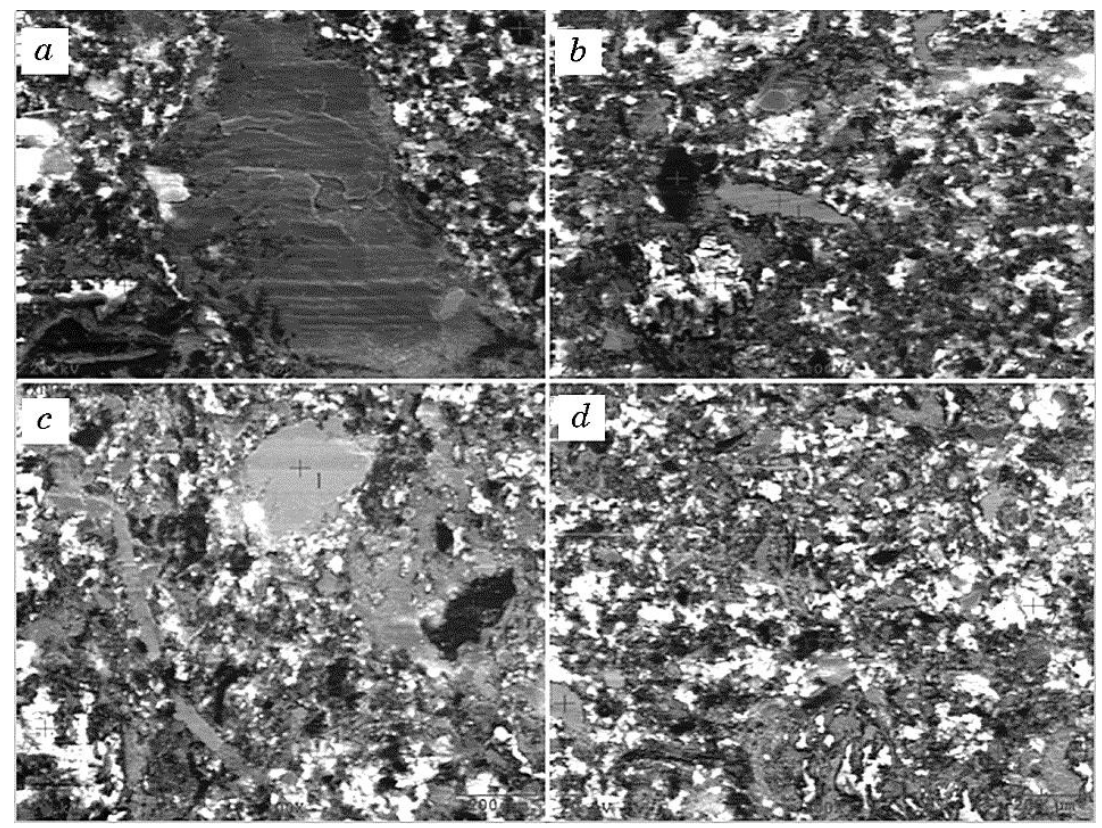

Fig. 6. SEM micrographs $(\times 200)$ of copper fibre-added specimens CF1.5 $(a)$, CF3 (b), CF4.5 (c), and CF6 (d).

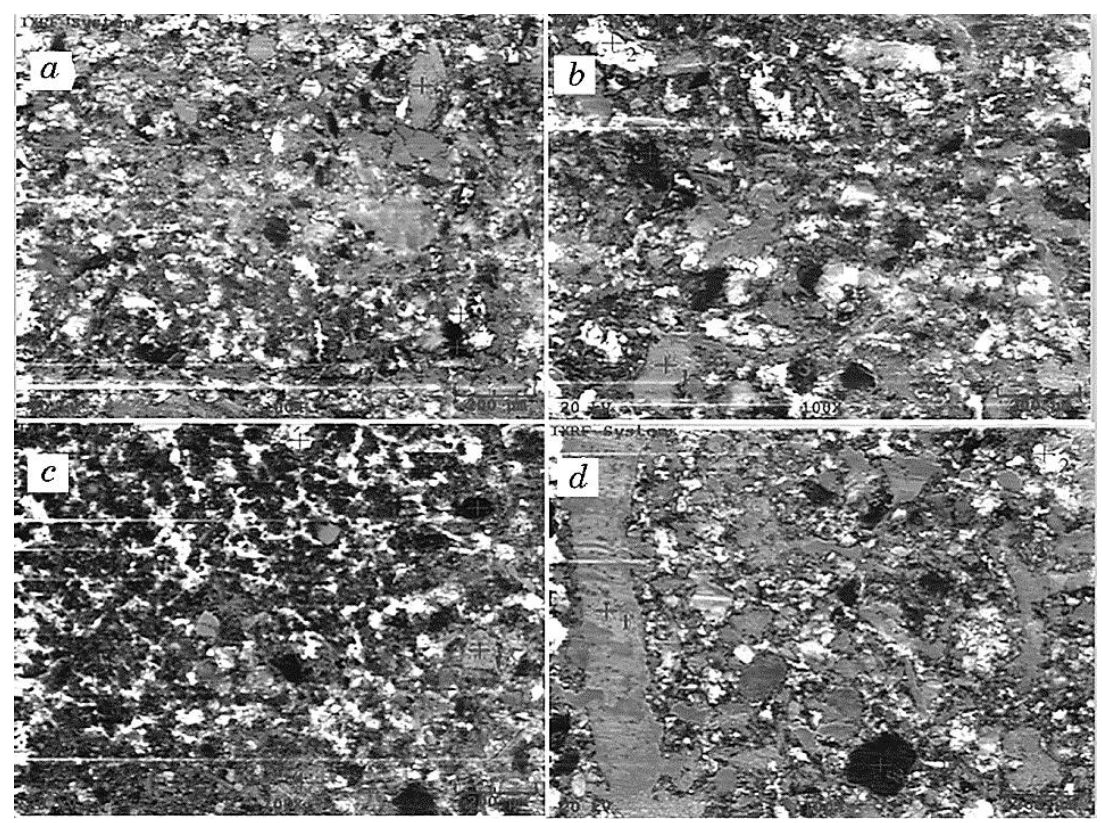

Fig. 7. SEM micrographs $(\times 200)$ of bronze fibre-added specimens BF1.5 $(a)$, BF3 $(b)$, BF4.5 $(c)$, and BF6 $(d)$. 
1. Addition of different amounts of borax powder enhances the wear resistance of brake pads, where thought in that, and the minimum wear rate and thickness loss were observed in BX5.

2. Friction test results show that fade and normal friction coefficient values are low; however, yet recovery and hot friction coefficients are within the desired range due to borax, and other components were not observed to be not forming a compatible compound, where thought.

3 . The addition of copper and bronze fibre increased recovery, normal, and hot friction coefficient values with increasing amount of metallic fibre, that e.g. CF6 and BF6 has have the maximum values. Considering test results and similar studies in the literature, $6 \%$ and above of metallic fibres' addition increases and improves the friction coefficient, while it increases the wear rate, where thought.

\section{REFERENCES}

1. R. Ertan and N. Yavuz, Wear, 268: 11 (2010).

2. S. J. Kim, K. S. Kim, and H. Jang, J. Mater. Process. Technol., 136, Nos. 1-3: $202(2003)$.

3. H. Jang, K. Ko, S. J. Kim, R. H. Basch, and J. W. Fash, Wear, 256, Nos. 3-4: 406 (2004).

4. T. R. Chapman, D. E. Niesz, R. T. Fox, and T. Fawcett, Wear, 236, Nos. 1-2: 81 (1999).

5. U. S. Hong, S. L. Jung, K. H. Cho, M. H. Cho, S. J. Kim, and H. Jang, Wear, 266, Nos. 7-8: 739 (2009).

6. I. Mutlu, C. Oner, and F. Findik, Materials and Design, 28, No. 2: 480 (2007).

7. I. Sugözü, I. Can, and C. Oner, Industrial Lubrication and Tribology, 66: 6 (2014).

8. M. Kumar and J. Bijwe, Wear, 269, Nos. 11-12: 826 (2010).

9. $\quad$ M. Kumar and J. Bijwe, Wear, 303, Nos. 1-2: 569 (2013).

10. M. Kumar and J. Bijwe, Tribology International, 44, No. 2: 106 (2011).

11. M. Kumar and J. Bijwe, Wear, 270, Nos. 3-4: 269 (2011).

12. P. Filip, Z. Weiss, and D. Rafaja, Wear, 252, Nos. 3-4: 189 (2002).

13. M. Eriksson and S. Jacobson, Tribology International, 33, No. 12: 817 (2000).

14. T. Singh and A. Patnaik, Archives of Civil and Mechanical Engineering, 15, No. 1: 142 (2015).

15. M. Kchaou, A. Sellami, R. Elleuch, and H. Singh, Materials and Design, 52: 533 (2013).

16. A. Sellami, M. Kchaou, R. Elleuchi, A.-L. Cristol, and Ya. Desplanques, Materials and Design, 59: 84 (2014).

17. B. Öztürk and S. Öztürk, Tribology Letters, 42: 339 (2011).

18. B. Öztürk, S. Öztürk, and A. Adigüzel, Tribology Transactions, 56: Iss. 3: 428 (2013). 